\title{
Novel aspects of platelet aggregation
}

\author{
Y. M. Roka-Moya, V. L. Bilous, D. D. Zhernossekov, T. V. Grinenko
}

Palladin Institute of Biochemistry, NAS of Ukraine

9, Leontovicha Str., Kyiv, Ukraine, 01601

chemikdd@mail.ru

\begin{abstract}
The platelet aggregation is an important process, which is critical for the hemostatic plug formation and thrombosis. Recent studies have shown that the platelet aggregation is more complex and dynamic than it was previously thought. There are several mechanisms that can initiate the platelet aggregation and each of them operates under specific conditions in vivo. At the same time, the influence of certain plasma proteins on this process should be considered. This review intends to summarize the recent data concerning the adhesive molecules and their receptors, which provide the platelet aggregation under different conditions.
\end{abstract}

Keywords: platelet aggregation, adhesive molecules.

Introduction. Platelets play an important role in hemostasis, thrombosis, wound healing, atherosclerosis, inflammation, immunity and tumor metastasis [1-3]. However, their main physiological function is the forming of hemostatic thrombi to prevent blood loss. The biochemical and cellular processes responsible for this function can be divided into four steps: adhesion, activation, secretion and aggregation. It is known that the platelets are exposed to a broad range of hemodynamic conditions in vivo, ranging from low-flow situations in venules and large veins $\left(<500 \mathrm{~s}^{-1}\right)$ to stenosed arteries with extremely high shear rates (till 40,000 s ${ }^{-1}$ ) [4]. Here we have considered the peculiarities of above mentioned steps under different hemodynamic conditions.

Platelet adhesion. The platelet adhesion is the process, through which the platelets establish contacts with the extracellular matrix. Under normal conditions the endothelial cells form a surface resistant to the adhesion of circulating platelets. The primary event, which leads to the platelet adhesion, is the damage of vessel wall. As the platelets are not able to distinguish between the traumatic vessel damage and the diseased arterial walls the same life saving reaction can become potentially dangerous in case of atherosclerosis. When the endothelial

\footnotetext{
(C) Institute of Molecular Biology and Genetics, NAS of Ukraine, 2014
}

cell layer of a vessel wall is damaged the components of subendothelial matrix, primarily collagen and von Willebrand factor (vWF) will be exposed to the blood. The initial tethering of the platelets to the extracellular matrix $(\mathrm{ECM})$ is mediated by the interaction between the platelet receptor glycoprotein GP Ib-IX-V and vWF bound to collagen [5]. It is noted that GP Ib can initiate the adhesion by interacting with other ligands. The most probable candidate for this role is thrombospondin-1 [6].

Using traditional aggregometry methods we have a model with low, nonlaminar shear conditions. To study the $\mathrm{vWF} / \mathrm{GP}$ Ib-IX-V interaction many investigators traditionally use ristocetin, a bacterial-derived antibiotic from Nocardia lurida. The vWF deficiency is accompanied with the absence or low level of the ristocetininduced aggregation whereas the ADP- or collagen-induced aggregation is normal. The absence of ristocetininduced aggregation can be also a result of the loss of $\mathrm{GP}$ Ib from the platelet surface. In this case the platelets of enormous size are determined in blood [7].

The binding site for GP Ib in the vWF structure is the A1 domain. In the vWF multimers, which circulate in blood, this domain is not accessible for interacting with the platelets. Binding to collagen under shear stress conditions leads to the conformational changes in the vWF molecule [8] and provides the platelet interaction with en- 


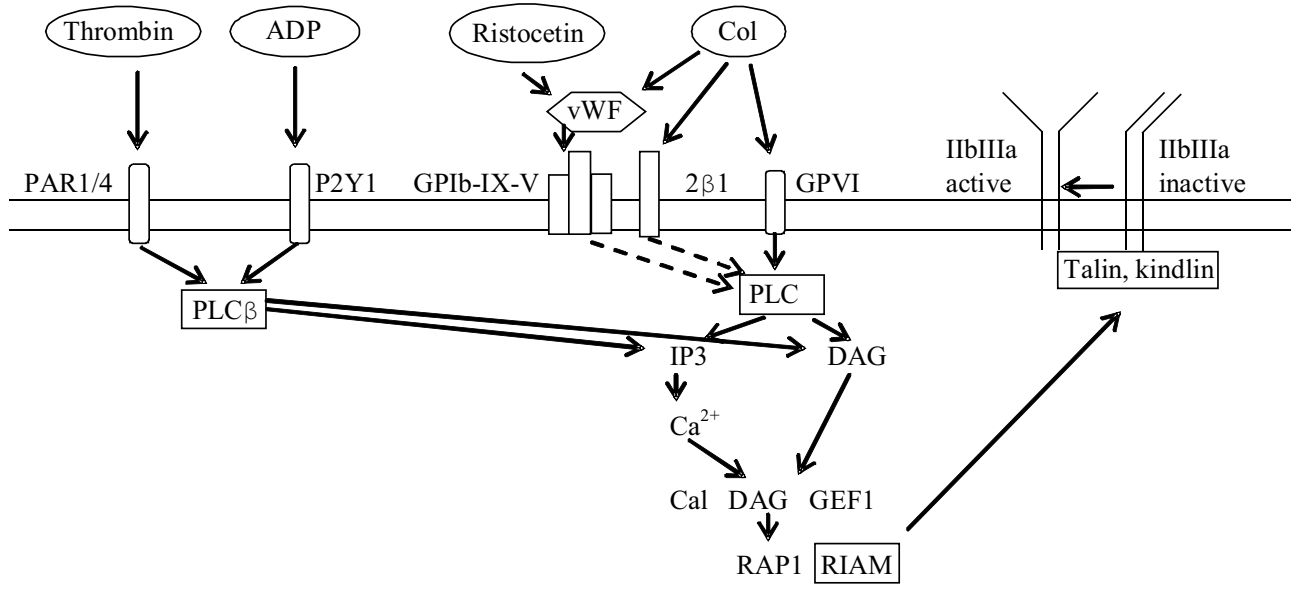

Fig. 1. Mechanisms of platelet aggregation induced by different agonists: $\mathrm{Col}-\mathrm{col}-$ lagen; $v W F$ - von Willebrand factor; $P L C$ - phospholipase; IP3 - inositol trisphosphate; $D A G$ - diacylglycerol; CalDAGGEF1 - calcium and DAG-regulated GEF1; RAP1 - Ras-related protein 1; RIAM - Rap-GTPinteracting adapter molecule dothelium collagen. This interaction is not strong enough to mediate stable adhesion but maintains the platelets in close contact with the surface. At this period the platelets establish additional contacts with collagen through the Ig-superfamily receptor, GP VI. This receptor is associated with the Fc-receptor, which bears the immunoreceptor tyrosine-based activation motifs (ITAM) for signal transduction. While GP VI binds collagen with low affinity, it triggers the shift of platelet integrins $\left(\alpha_{2} \beta_{1}\right.$ and IIbIIIa) to a high-affinity state. The main steps of this process are shown in Fig. 1. The integrin collagen receptor $\alpha_{2} \beta_{1}$ binds to collagen and facilitates the engagement of GP VI [9].

Platelet activation. When GP VI is crosslinked and clustered by collagen, this leads to the activation of the Src tyrosine kinases (Fyn and Lyn) bound to the cytoplasmatic tail of GP VI. The ITAMs present on the FcR $\gamma$-chain are phosphorylated by Fyn and Lyn, next allowing for the involvement of the tyrosine kinase Syk. Syk in turn induces a signaling cascade resulting in the activation of phospholipase $\mathrm{C} \gamma(\mathrm{PlC} \gamma)$. This enzyme hydrolyzes phosphatidylinositol 4,5 bisphosphate to produce inositol trisphosphate (IP3) and diacylglycerol (DAG), which activate calcium mobilization and protein kinase $\mathrm{C}$, respectively. Increased calcium levels lead to the activation of the $\mathrm{Ca}^{2+}$ and DAG-regulated guanine nucleotide exchange factor I (Cal DAG-GEFI), which itself activates Rap 1b, a small GTP binding protein. The interaction of activated Rap $1 \mathrm{~b}$ with the Rap 1-interacting adaptor molecule (RIAM) and talin results in the formation of an «activation complex». The interaction of talin with Rap1b and RIAM leads to the unmasking of the integrin-binding site on talin. Talin hence binds to the integrin $\beta_{3}$ tail, which leads to the disruption of the clasp between $\alpha$ and $\beta$ subunits of IIbIIIa integrin. This separation of the integrin cytosolic region is transmitted to the extracellular domains which change from a bent to an extended conformation. Recently it has been shown that kindlin is also an important mediator of the integrin activation [10]. However, the interplay between talin and kindlin in the integrin activation still needs to be elucidated. After the activation IIbIIIa integrin acquires abilities to bind fibrinogen and other adhesive ligands [11]. The numerous works provide evidence that IIbIIIa the integrin activation occurring in response to the external signals results in internal changes [12-14]. During the activation, the cytoskeletal reorganization takes place and this event is considered to be one of the earliest hallmark of the platelet activation. In the activated platelets, the rapid F-actin polymerization and formation of complex between the membrane cortex cytoskeleton and the cytoplasmic filaments are observed. Remodeling of the actin cytoskeleton is necessary for the blood coagulation because the actin filaments in the activated platelets mediate such crucial processes as the adherence to extracellular matrix and to other cells, extension of filopodia and lamellipodia, maintenance of the platelet morphology, contraction of the inner central cytoplasm facilitating the expulsion of granule content such as growth factors and vasoactive substances, ultimately contraction of the whole cell, which is required for the clot retraction [15]. Thus, the integrins provide a transmembrane linkage between the cytoskeleton and the extracellular matrix. It has been revealed that the cytoskeleton plays a critical role in the two-way communication across the integrins: binding of extracellular 
adhesive molecule to the integrin regulates the organization of cytoskeleton, in turn the cytoskeleton regulates the adhesive properties of the integrin [16,17]. It is welldocumented that cytochalasins, which disrupt the actin fibers, cause the integrin to dissociate from its adhesive ligand, and the cytochalasin-treated platelets fail to aggregate even in the presence of agonists [18]. Besides, the activated platelets, as well as several types of cancer and normal cells, are able to expose actin on the surface of their plasma membrane. It is suggested that the surface actin may play a role of specific site for binding some molecules regulating the platelet adhesion and aggregation [19].

Speaking about the platelet activation, we have to pay attention to the most potent platelet activator, thrombin. Small amounts of thrombin are formed on the surface of a tissue factor presenting cell (fibroblast or activated monocyte or activated endothelial cell, respectively). These amounts of thrombin are not able to produce a stable fibrin clot, but are enough to activate the platelets. Thrombin binds the protease-activated receptors (PAR-1 and PAR-4) on the platelet surface. The following signaling mechanism includes the activation of phospholipase $C \beta$ (see Fig. 1). Thrombin also binds GP-Ib, which has been proposed to enhance the specificity of thrombin cleavage of PAR-1 [20].

Platelet secretion. The activated platelets release several granule components, which modulate functions of the interacting platelets. The dense bodies of the platelets contain secondary agonists like ADP and serotonin. There are two important ADP receptors on the platelet surface. The P2Y1-receptor modulates the calcium mobilization and shape change [21]. The PY12-receptor potentiates the platelet secretion and is involved in the irreversible aggregation [22]. Serotonin binds to the Gq-coupled receptor and together with ADP amplifies the platelet response. Additionally, serotonin may play a specific role in the retention of fibrinogen and thrombospondin on the platelet surface [23]. The platelet activation also results in the releasing of $\alpha$-granule proteins: adhesive molecules (vWF, thrombospondin, vitronectin and fibronectin), mitogenic factors, coagulation factors and protease inhibitors. P-selectin is exclusively localized on the $\alpha$-granule membrane of the resting platelets. However, during the secretion it migrates on the platelet surface as a result of the fusion of $\alpha$-gra- nule membrane with the plasma membrane. This adhesive protein mediates the platelet binding with leukocytes [24].

Platelet aggregation. The main mechanism of the platelet aggregation is thought to be realized through the interaction of fibrinogen with integrin IIbIIIa [25]. However, other adhesive molecules, such as thrombospondin, vWF, vitronectin and fibronectin are necessary to provide effective aggregation (see Fig. 2). It was shown that fibrinogen, vWF and fibronectin have similar binding affinities to the activated form of IIbIIIa [26]. Under low shear conditions, fibrinogen is the dominant ligand of the platelet aggregation thanks to its high molar ratio in plasma compared with other ligands. In vivo studies on mice with a targeted deletion of $\mathrm{vWF}$ or fibrinogen demonstrated that $\mathrm{VWF}$ plays a main role in initiating aggregation under high shear with fibrinogen (and fibrin) playing a secondary role in stabilizing the formed aggregates. The thrombus formation still occurs in mice lacking both vWF and fibrinogen [27], which suggests that other proteins (fibronectin, thrombospondin and vitronectin) may be able to mediate the platelet adhesion and aggregation. In vitro studies showed that the second wave of the thrombin-induced aggregation of gel-filtered the platelets was abolished at a low concentration of thrombin in the vitronectin-deficient platelets [28]. Contrary to the released platelet granule vitronectin, which enhances the platelet aggregation, the plasma vitronectin inhibits the platelet aggregation. The role of vWF in the platelet aggregation is also significant. In high shear environments the platelets are the first linked by vWF bridges via the GP Ib/V/IX complex. This interaction leads to the activation of the integrin IIbIIIa and in turn to the stabilization of the vWFmediated platelet aggregates [29]. The recent studies on mice, which express low levels of the plasma and platelet fibronectin have confirmed the involvement of this protein in the platelet aggregation [30]. Fibronectin is able to bind fibrinogen and thrombospondin, thus increasing the stability of the platelet-platelet interactions [31]. Similar to vWF, fibronectin undergoes conformational changes in response to the mechanical stress [32]. That can explain the role of fibronectin in promoting of thrombus formation under high shear. Notably, a combination of ligands (such as vWF/fibrinogen or fibronectin/fibrin) is far more reactive to the platelets than 

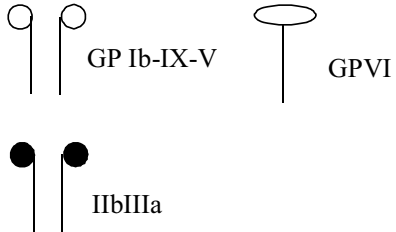

IIbIIIa

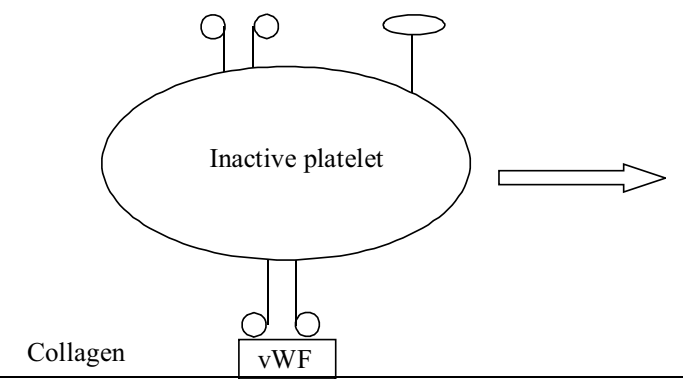

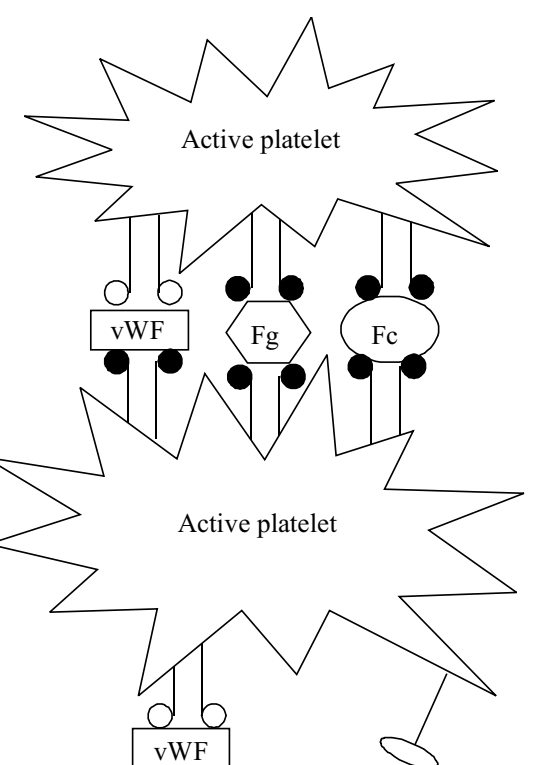

Fig. 2. The scheme of platelet aggregation: $v W F$ - von Willebrand factor; $F g$ - fibrinogen; $F c$ - fibronectin in isolation. It can be important because the elevated plasma levels of vWF, fibrinogen, and possibly fibronectin independently increase a risk of the atherothrombotic complications [33].

There are some interesting data about the influence of some plasma proteins on the platelet aggregation. Among them, plasminogen, a 92-kDa single-chain zymogen, is essential for efficient fibrinolysis and facilitates cell migration. Plasminogen can be considered as an adhesive ligand for the integrins found on the surface of the platelets and leucocytes [34]. It is known that plasminogen binds to the platelet surface, and the activated platelets possess an increased affinity to plasminogen [35]. Moreover, for the hemodialysis patients the correlation between plasminogen level in plasma and the platelet aggregation was observed [36]. Recently, we have studied the effect of Lys- and Glu-plasminogen on the human platelet aggregation [37, 38]. Under physiological conditions, Lys-plasminogen and Lys-plasmin are not present in circulating blood [39]. However, in the patients undergoing thrombolytic therapy using the tissue plasminogen activator, a low amount of Lys-plasminogen was detected [39]. We have shown that Lysplasminogen but not its Glu-form inhibits the thrombinand collagen-induced aggregation in the preparations of washed human platelets. The level of aggregation in both cases decreases at least by two times. It has been found that $\varepsilon$-aminocaproic acid $(1 \mathrm{mM})$ abolishes the inhibitory effect of Lys-plasminogen that is compatible with the participation of lysine-binding sites of 1-5 kringles of the proenzyme in the inhibitory process. We have shown that kringle $1-3$, kringle 5 and kringle 4 act as competitors of the proenzyme molecule when they were incubated with the washed platelets and exogeneous Lys-plasminogen. It is quite possible that Lys-plasminogen binds some proteins, which are released during the $\alpha$-granule secretion and stay bound with the platelet membrane (such as fibrinogen, thrombospondin, vitronectin etc.). So, exogeneous Lys-plasminogen could impede the formation of platelet aggregates.

The relationship between the adhesive ligands and the platelet receptors can also be important considering the side effects of some anticoagulants. It is well known, that the heparin preparations influence the platelet aggregation. It was shown, that heparin induces a slight increase of the platelet aggregation in the platelet rich plasma preparations meanwhile the significant inhibitory activity is observed when heparin was added to the washed platelets [40]. The most pronounced inhibitory effect was in case of the ristocetin-induced aggregation however with other agonists (thrombin, epinephrine and ADP) it also took place. It was found that heparin is able to associate directly with the major platelet integrin IIbIIIa triggering a signaling cascade that leads to the activation of phosphatidyl-inositol-3-kinase [41]. On the other hand, IIbIIIa is not the only side for heparin because the latter can bind numerous platelet protein compounds of the platelet $\alpha$-granule, including vWF, 
fibronectin, thrombospondin and vitronectin [42-45]. Taking into consideration all the above mentioned data, we can make the following suggestion. In the plasma preparations where fibrinogen is abundant, an influence of other adhesive ligands is not crucial, so heparin shows its stimulating effect. In case of the washed platelets the efficiency of platelet aggregation depends on the binding of $\alpha$-granule proteins with the platelet receptors (IIbIIIa and GP I/IX/V). So, heparin can bind the adhesive ligands and impede the platelet aggregation. Probably, the interaction GP Ib-vWF is the main site of the heparin influence.

Perspectives. In the recent years, both in vitro and in vivo studies on the structure and function of the platelet adhesion molecules have provided new insights into the platelets interaction with the injured vessel wall and with each other under different conditions. The obtained results can be important not only for a better understanding of the molecular mechanisms underlying thrombosis, but also may reveal new therapeutic targets for the treatment of disorders such as the inflammatory diseases, atherosclerosis, and cancer.

Нові аспекти агрегації тромбоцитів

Я. М. Рока-Мойя, В. Л. Білоус, Д. Д. Жерносєков, Т. В. Гриненко

Резюме

Відомо, що агрегаиія тромбоцитів - ие важливий процес, якийлежить в основі утворення гемостатичної пробки та формування тромба. Однак останні дослідження показали, щзо тромбоциттарна агрегація є значно складнішим і динамічнішим процесом, ніж вважали раніме. Існує декілька механізмів, які ініціюють агрегацію тромбоцитів, $i$ кожен із них реалізується за певних умов іп vivo. У той же час необхідно враховувати вплив на цей процес окремих білків плазми крові. Мета даного огляду - узагальнити сучасні дані, присвячені адгезивним молекулам та їхнім рецепторам, які забезпечують тромбоиитарну агрегацію за різних умов.

Ключові слова: агрегачія тромбочитів, адгезивні молекули.

Новые аспекты агрегации тромбоцитов

Я. М. Рока-Мойя, В. Л. Билоус, Д. Д. Жерносеков, Т. В. Гриненко

Резюме

Известно, что агрегация тромбочитов является важным проиессом, лежащим в основе образования гемостатической пробки и формирования тромба. Однако недавние исследования показали, что тромбоцитарная агрегация - это более сложный и динамичный процесс, чем считали ранее. Сущзествует несколько механизмов, инициирующих агрегацию тромбочитов, и каждый из них реализуется при определенных условиях іп vivo. В то же время необходимо учитывать влияние на этот процесс отдельных белков плазмы крови. Цель настоящего обзора - обобщить современные данные, посвященные адгезивным молекулам и их рецеп- торам, обеспечивающим тромбочитарную агрегащию в различных условиях.

Ключевые слова: агрегация тромбоцитов, адгезивные молекульы.

\section{REFERENCES}

1. Semple JW, Italiano JE Jr, Freedman J. Platelets and the immune continuum. Nat Rev Immunol. 2011; 11(4):264-74.

2. Boilard E, Nigrovic PA, Larabee K, Watts GF, Coblyn JS, Weinblatt ME, Massarotti EM, Remold-O'Donnell E, Farndale RW, Ware J, Lee DM. Platelets amplify inflammation in arthritis via collagen-dependent microparticle production. Science. 2010; 327(5965):580-3.

3. Leslie M. Beyond clotting: the powers of platelets. Science. 2010; 328(5978):562-4.

4. Bluestein D, Niu L, Schoephoerster RT, Dewanjee MK. Fluid mechanics of arterial stenosis: relationship to the development of mural thrombus. Ann Biomed Eng. 1997; 25(2):344-56.

5. Li Z, Delaney $M K, O$ 'Brien $K A$, Du X. Signaling during platelet adhesion and activation. Arterioscler Thromb Vasc Biol. 2010; 30(12):2341-9.

6. Jurk K, Clemetson KJ, de Groot PG, Brodde MF, Steiner M, Savion N, Varon D, Sixma JJ, Van Aken H, Kehrel BE. Thrombospondin-1 mediates platelet adhesion at high shear via glycoprotein $\mathrm{Ib}(\mathrm{GP} \mathrm{Ib})$ an alternative/ backup mechanism to von Willebrand factor. FASEB J. 2003; 17(11):1490-2.

7. Zubovskaja ET, Svetlizkaja SG. Hemostasis system. Theoretic bases and investigation methods. Minsk: BGUFK, 2010; 310 p.

8. Siedlecki CA, Lestini BJ, Kottke-Marchant KK, Eppel SJ, Wilson DL, Marchant RE. Shear-dependent changes in the three-dimensional structure of human von Willebrand factor. Blood. 1996; 88(8):2939-50.

9. Wohner N. Role of cellular elements in thrombus formation and dissolution. Cardiovasc Hematol Agents Med Chem. 2008; 6(3): 224-8.

10. Moser M, Nieswandt B, Ussar S, Pozgajova M, Fassler R. Kindlin-3 is essential for integrin activation and platelet aggregation. Nat Med. 2008; 14(3):325-30.

11. Broos K, De Meyer SF, Feys HB, Vanhoorelbeke K, Deckmyn H. Blood platelet biochemistry. Thromb Res. 2012; 129(3):245-9.

12. Shattil SJ, Newman PJ. Integrins: dynamic scaffolds for adhesion and signaling in platelets. Blood. 2004; 104(6):1606-15.

13. Jirouskova M, Jaiswal JK, Coller BS. Ligand density dramatically affects integrin alpha IIb beta 3 -mediated platelet signaling and spreading. Blood. 2007; 109(12):5260-9.

14. Fox JE. Transmembrane signaling across the platelet integrin glycoprotein IIb-IIIa. Ann N Y Acad Sci. 1994 714:75-87.

15. Fox JE. The platelet cytoskeleton. Thromb Haemost. 1993; 70 (6):884-93.

16. Leisner TM, Wencel-Drake JD, Wang W, Lam SC. Bidirecti nal transmembrane modulation of integrin alphaIIbbeta3 conformations. J Biol Chem.1999; 274(18):12945-9.

17. Kurtz L, Kao L, Newman D, Kurtz I, Zhu Q. Integrin $\alpha \operatorname{IIb} \beta 3$ inside-out activation: an in situ conformational analysis reveals a new mechanism. J Biol Chem. 2012; 287(27):23255-65.

18. May JA, Ratan H, Glenn JR, Losche W, Spangenberg P, Heptinstall $S$. GPIIb-IIIa antagonists cause rapid disaggregation of platelets pre-treated with cytochalasin D. Evidence that the stability of platelet aggregates depends on normal cytoskeletal assembly. Platelets. 1998; 9(3-4):227-32.

19. Tykhomyrov $A A$. Interaction of actin with plasminogen/plasmin system: mechanisms and physiological role. Biopolym Cell 2012; 28(6):413-23. 
20. Jennings $L K$. Mechanisms of platelet activation: need for new strategies to protect against platelet-mediated atherothrombosis. Thromb Haemost. 2009; 102(2):248-57.

21. Fabre JE, Nguyen M, Latour A, Keifer JA, Audoly LP, Coffman $T M$, Koller BH. Decreased platelet aggregation, increased bleeding time and resistance to thromboembolism in P2Y1-deficient mice. Nat Med. 1999; 5(10):1199-202.

22. Dorsam RT, Kunapuli SP. Central role of P2Y 912 receptor in platelet activation. $J$ Clin Invest. 2004; 113(3):340-5.

23. Dale GL, Friese P, Batar P, Hamilton SF, Reed GL, Jackson $K W$, Clemetson KJ, Alberio L. Stimulated platelets use serotonin to enhance their retention of procoagulant proteins on the cell surface. Nature. 2002; 415(6868):175-9.

24. Singbartl K, Forlow SB, Ley K. Platelet, but not endothelial, Pselectin is critical for neutrophil-mediated acute postishemic renal failure. FASEB J. 2001; 15(13):2337-44.

25. Marguerie G, Ginsberg MH, Plow EF. Glycoproteins: the fibrinogen receptor. Platelet responses and metabolism. Responsemetabolism relationships / Ed. H. Holmsen Boca-Raton: CRC Press. Inc., 1986; Vol. III:286-94.

26. Gralnick HR, Williams SB, Coller BS. Fibrinogen competes with von Willebrand factor for binding to the glycoprotein $\mathrm{IIb}$ /IIa complex when platelets are stimulated with thrombin. Blood. 1984; 64(4):797-800.

27. Ni H, Denis CV, Subbarao S, Degen JL, Sato TN, Hynes RO, Wagner $D D$. Persistence of platelet thrombus formation in arterioles of mice lacking both von Willebrand factor and fibrinogen. J Clin Invest. 2000; 106(3):385-92.

28. Reheman A, Gross P, Yang H, Chen P, Allen D, Leytin V, Freedman $J, N i H$. Vitronectin stabilizes thrombi and vessel occlusion but plays a dual role in platelet aggregation. J Thromb Haemost. 2005; 3(5):875-83.

29. Ruggeri $Z M$. Mechanisms of shear-induced platelet adhesion and aggregation. Thromb Haemost. 1993; 70(1):119-23.

30. Ni H, Yuen PS, Papalia JM, Trevithick JE, Sakai T, Fassler R, Hynes $R O$, Wagner $D D$. Plasma fibronectin promotes thrombus growth and stability in injured arteriols. Proc Natl Acad Sci USA. 2003; 100(5):2415-9.

31. Cho J, Mosher DF. Role of fibronectin assembly in platelet thrombus formation. J Thromb Haemost. 2006; 4(7):1461-9.

32. Hynes RO. The dynamic dialogue between cells and matrices: implications of fibronectin's elasticity. Proc Natl Acad Sci USA. 1999; 96(6):2588-90.

33. Jackson SP. The growing complexity of platelet aggregation. Blood. 2007; 109(12):5087-95.

34. Lishko VK, Novokhatny VV, Yakubenko VP, Skomorovska-Prokvolit HV, Ugarova TP. Characterization of plasminogen as an ad- hesive ligand for integrins $\alpha_{M} \beta_{2}$ (Mac-1) and $\alpha_{5} \beta_{1}$ (VLA-5). Blood. 2004; 104(3):719-26.

35. Horne MK, Merryman PK, Cullinane AM. Plasminogen interaction with platelets: the importance of carboxyterminal lysines. Thromb Res. 2005; 116(6):499-507.

36. Salobir B, Sabovic M, Zupan IP, Ponikvar JB. Platelet (dys) function and plasma plasminogen levels in hemodialysis patients. Ther Apher Dial. 2008; 12(2):133-6.

37. Roka-Moya YM, Zhernossekov DD, Zolotareva EM, Grinenko $T V$. The influence of exogenous Lys-plasminogen on ADP-induced platelet aggregation. Bulletin of Taras Shevchenko National University of Kyiv. Series: Biology. 2011; 58:34-6.

38. Roka-Moya YM, Zhernossekov DD, Grinenko TV. Plasminogen/ plasmin influence on platelet aggregation. Biopolym Cell. 2012; 28(5):352-6.

39. Holvoet $P$, Lijnen HR, Collen D. A monoclonal antibody specific for Lys-plasminogen. Application to the study of the activation pathways of plasminogen in vivo. J Biol Chem. 1985; 260 (22):12106-11.

40. Saba HI, Saba SR, Morelli GA. Effect of heparin on platelet aggregation. Am J Hematol. 1984; 17(3):295-306.

41. Gao C, Boylan B, Fang J, Wilcox DA, Newman DK, Newman $P J$. Heparin promotes platelet responsiveness by potentiating $\alpha$ II $\beta 3$-mediated outside-in signaling. Blood. 2011; 117(18): 4946-52.

42. Fujimura Y, Titani K, Holland LZ, Roberts JR, Kostel P, Ruggeri ZM, Zimmerman TS. A heparin-binding domain of human von Willebrand factor: characterization and localization to a tryptic fragment extending from amino acid residue Val-449 to Lys728. J Biol Chem. 1987; 262(4):1734-9.

43. Bentley KL, Klebe RJ, Hurst RE, Horowitz PM. Heparin binding is necessary, but not sufficient for fibronectin aggregation. A fluorescence polarization study. J Biol Chem. 1985; 260(12): 7250-6.

44. Yu H, Tyrrel D, Cashel J, Guo NH, Vogel T, Sipes JM, Lam L, Fillit HM, Hartman J, Mendelovitz S, Panel A, Roberts DD. Specificities of heparin-binding sites from the amino-terminus and type 1 repeats of thrombospondin-1. Arch Biochem Biophys. 2000; 374(1): 13-23

45. Edens RE, LeBrun LA, Linhardt RJ, Kaul PR, Weiler JM. Certain high molecular weight heparin chains have high affinity for vitronectin. Arch Biochem Biophys. 2001; 391(2):278-85.

Received 15.07.13 